\title{
INVESTIGATION OF FERTILISATION IMPACT ON FRESH STRAWBERRIES YIELD AND QUALITY PARAMETERS
}

\author{
Karlis Sprogis, Tatjana Kince, Sandra Muizniece-Brasava \\ Department of Food Technology, Faculty of Food Technology, Latvia University of Agriculture, Rigas Street 22, Jelgava, Latvia, \\ e-mail: karlissprogis@inbox.lv
}

\begin{abstract}
Strawberries are a choice fruit crop for many home gardeners. The low-growing plants are reliable and quick to produce. June bearers provide a delicious supply of fruit from late spring through early summer, while day-neutral types produce berries throughout the summer. The main purpose of the current research was to evaluate fertilizers impact on strawberries yield and quality parameters. In the experiments freshly picked garden strawberries cv Polka harvested in Koknese region (Latvia) in July 2016 were analysed. For strawberries fertilization Ferticare ${ }^{\mathrm{TM}}$ Kombi 1 (NPK 14-11-25+micro) with and without $\mathrm{Ca}\left(\mathrm{NO}_{3}\right)_{2}$, YaraLiva ${ }^{\mathrm{TM}}$ Calcinit with and without $\mathrm{Ca}\left(\mathrm{NO}_{3}\right)_{2}$ were applied at the rate $100 \mathrm{~kg} \mathrm{~N} \mathrm{ha}^{-1}$ and $50 \mathrm{~kg} \mathrm{~N} \mathrm{ha}^{-1}$. As a control, strawberries without fertilizer were analysed. The main quality parameters were tested using standard methods: yield $\left(\mathrm{t} \mathrm{ha}^{-1}\right)$; berries firmness $(\mathrm{N})$; $\mathrm{pH}$; nitrate content $\left(\mathrm{mg} \mathrm{kg}^{-1}\right)$; soluble solids ( ${ }^{\circ}$ Brix); extra, proportion of I and II class berries from total yield (\%); sensory properties of strawberries (line scale). During the current research significant impact of nitrogen fertilizer on the $\mathrm{pH}$ and firmness of strawberries, the content of soluble solids, nitrates content in berries, as well as the yield has been established. As a result, $50 \mathrm{~kg}$ of nitrogen fertilizer per hectare should be recommendable during spring strawberries fertilization with NPK 14-11-25+micro when the strawberry yield were 12.7 tons, the berry firmness was $0.94 \mathrm{~N}, \mathrm{pH}$ was 3.67 , nitrates in berries was below $36 \mathrm{mg} \mathrm{kg}^{-1}$, the content of the soluble solids was $11.8{ }^{\circ}$ Brix and the proportion of Extra, I and II categories berries was $83 \%$ from total yield.
\end{abstract}

Keywords: strawberries, fertilization, quality parameters.

\section{Introduction}

Fruits such as strawberry (Fragaria $\times$ ananassa Duch.) are characterized as being small and fleshy and are consumed in many countries, primarily fresh however as processing products too. Recently, consumers' interest in berries has grown due to their beneficial health effects because of the antioxidant and anticancer properties and for being a good source of fibre, vitamins, folic acid, fatty acids, polyphenols and minerals (Corrêa Pereira et al., 2016). Traditionally strawberry growth requires a considerable amount of water to establish plantings, and depends on frequent applications of pesticides to produce acceptable fruit quality (Pritts, 2002). Cultivation, variety, fertilization, region and weather conditions as well as sampling time and degree of ripeness significantly affect the nutritive value of strawberries and its final quality parameters. Strawberries need moderate fertilization and irrigation, as well as nearly neutral (6-6.5) soil $\mathrm{pH}$ (Hakala et al., 2003). Some research data suggest that nitrogenous fertilizers used in agriculture contaminate surface and underground waters, enhance $\mathrm{N}_{2} \mathrm{O}$ emissions into the atmosphere resulting in possible nitrate accumulation in plants (Pešaković et al., 2013). In research, based on fruit quality, fruit quantity, water and nitrogen use efficiencies, nitrogen treatment (450 kg N ha-1) would be the most appropriate nitrogen fertilizer application for vegetables by subsurface drip irrigated under the similar plant growth conditions in solar greenhouses (He-xi et al., 2011). Nitrogen is a special mineral nutrient absorbed by the roots of plants. It can be present in the soil either in mineral form, such as $\mathrm{NO}_{3}^{-}$and $\mathrm{NH}_{4}^{+}$, or as organic compounds, such as amino acids, resulting from the mineralization of complex organic $\mathrm{N}$ forms. In general, strawberry is highly sensitive to mineral $\mathrm{N}$ in soil. Many farmers fail to cultivate this crop because it is not possible to apply chemical $\mathrm{N}$ fertilizers properly (Wang et al., 2009). However, $\mathrm{CaCl}_{2}$ dips or controlled atmospheres can help maintain firmness and visual quality resulting in a longer shelf-life of the fresh-cut products as strawberries (Aguayo et al., 2006) after harvesting mainly. Calcium is considered as one of the most important nutrient elements in controlling the metabolism of plant cells. Its role in preventing various physiological disorders is well known. In addition, it is also known as retardant of fruit ripening and senescence processes. Though, the mechanism by which calcium prevents physiological disorders is not well understood, however it is known that it principally acts on middle lamella of cell wall and plays its role of cross-linking, where it may influence membrane bound enzymes too (Sharma et al., 2006). The consumer attitude towards food is very complex, as it is influenced by sensory and non-sensory attributes, as well as by the interactions between them. Consumer concerns include production and preservation technologies, contextual influences, social factors, health, ethnic and cultural concepts and price (Filho et al., 2014). Sensory characteristics of food can be considered as one of the key factors in food acceptance. People prefer to eat what is tasty, but the importance of food taste may differ between individuals. The healthiness of berries or berry products can also be an important factor affecting their acceptance and consumption. Possible disclosure of the health-related effects may have a positive impact on consumer acceptance (Jaeger et al. 2009; Laaksonen et al., 2016). The main purpose of the current research was to evaluate fertilizers impact on strawberries yield and quality parameters. 


\section{Materials and Methods}

Materials and experiment steps

The investigations were carried out at Latvia University of Agriculture and JSP-Latvia in 2016. For strawberries non-root fertilization Ferticare $^{\mathrm{TM}}$ Kombi 1 (NPK 14-11-25+micro) (Kombi) (content: $\mathrm{N}_{2}$ 14\%, $\mathrm{P}_{2} \mathrm{O}_{5} 11.6 \%, \mathrm{~K}_{2} \mathrm{O} 25.3, \mathrm{MgO} 2.4 \%, \mathrm{~S} 13.75 \%, \mathrm{~B}$ $0.02 \%, \mathrm{Cu} 0.01 \%$, Fe $0.1 \%$, Mn $0.1 \%$, Mo $0.002 \%$ and Zn $0.01 \%$ ), as well as YaraLiva ${ }^{\mathrm{TM}}$ Calcinit (Calcinit) (content: N 15.5\%, CaO 26.2\%) were used. During fertilization extra $50(N 50)$ or 100 (N100) $\mathrm{kg} \mathrm{N} \mathrm{ha}^{-1}$, however $\mathrm{Ca}\left(\mathrm{NO}_{3}\right)_{2}(\mathrm{Ca})$ were added. The scheme of the experiments was as follows:

1) no fertilizers (control)

2) $\mathrm{Kombi}+\mathrm{Ca}\left(\mathrm{NO}_{3}\right)_{2}+\mathrm{N} 100(\mathrm{~K} / \mathrm{Ca} / \mathrm{N} 100)$

3) $\mathrm{Kombi}+\mathrm{Ca}\left(\mathrm{NO}_{3}\right)_{2}+\mathrm{N} 50(\mathrm{~K} / \mathrm{Ca} / \mathrm{N} 50)$

4) $\mathrm{Kombi}+\mathrm{N} 100(\mathrm{~K} / \mathrm{N} 100)$

5) $\mathrm{Kombi}+\mathrm{N} 50(\mathrm{~K} / \mathrm{N} 50)$

6) Calcinit $+\mathrm{Ca}\left(\mathrm{NO}_{3}\right)_{2}+\mathrm{N} 100(\mathrm{Ca} / \mathrm{Ca} / \mathrm{N} 100)$

7) Calcinit $+\mathrm{Ca}\left(\mathrm{NO}_{3}\right)_{2}+\mathrm{N} 50(\mathrm{Ca} / \mathrm{Ca} / \mathrm{N} 50)$

8) Calcinit + N $100(\mathrm{Ca} / \mathrm{N} 100)$

9) Calcinit + N $50(\mathrm{Ca} / \mathrm{N} 50)$

The investigations were carried out in a strawberry plantation located in Koknese region (Latvia). Strawberry cv Polka was used for the experiments. Berries were harvested in July 2016. The experiment was designed in random blocks, number of replications -3 . The soil in the experimental plot was with $\mathrm{pH}$ 6.4. For strawberries' providing with calcium six time fertilization with $\mathrm{Ca}\left(\mathrm{NO}_{3}\right)_{2}$ was applied by $0.45 \mathrm{~kg} \mathrm{~N}$ $\mathrm{ha}^{-1}$ during one fertilization.

\section{Yield calculation}

Strawberries were picked three times a week, before they reached fully red colour, but when they had reached 85 to 89 growth stage (according to the scale). Harvested strawberries were divided in three classes regarding requirements that are needed for realization of fresh berries. Extra class strawberries are equal and normal regarding readiness (right shape and colour) as well as size; they are bright and clean, without any soil or any other dirt. Berry size was above $25 \mathrm{~mm}$ (measuring by the biggest diameter). Class I, class II strawberries can have slight shape defects, small white spots, they may differ in size. They are practically clean - without soil or any dirt. Size was above $18 \mathrm{~mm}$. To ease work for berry pickers and have berries sorted by standards already at the farmstead there are informative guidelines with strawberry class samples. Class II strawberries have shape defects, white stains that are not more than one fifth of berry surface, slight dry abrasions. Berries may have a little soil, but no other dirt. In both sorted harvestings berries were healthy, clean (without any visible dirt, fresh and unwashed, without visible pest damage, with sepal, without foreign smell or taste).

\section{Firmness}

Texture analyser TA.HD plus (United Kingdom) was applied for evaluation of strawberries surface firmness. For the testing $5 \mathrm{~mm}$ cylindrical stainless probe was used with speed of $1 \mathrm{~mm} \mathrm{~s}^{-1}$ and trigger force $0.049 \mathrm{~N}$ on berries surface. For texture evaluation of 10 separate fruits was completed.

$p H$

Berries $\mathrm{pH}$ was evaluated using $\mathrm{pH}$ meter "Lutron PH-212" (Taiwan) according to LVS ISO 1132:2001 by immersing an electrode in blended berry mass.

Nitrate content

Nitrate content in berries was analysed according to GOST 29270-9 ionometric method. Experiments was realised in 3 reiterations.

\section{Soluble solids}

Soluble solids content of berries was measured with a Kruss Optronic digital hand refractometer DR 301-95 (Germany) in ${ }^{\circ}$ BRIX according to LVS ISO 12143:2001.

\section{Berries sensory properties}

Berries sensory properties were evaluated using $15 \mathrm{~cm}$ line-scale (taste, hardness and colour) according to ISO 4121:2003.

\section{Statistical analysis}

Experimental results were analysed by Microsoft Excel 2013. Analysis of variance (ANOVA) and Tukey's tests were used to determine differences among samples. Differences were considered as significant at $\mathrm{p}<0.05$.

\section{Results and Discussion}

\section{Yield and Nitrates}

Nitrogen (N) fertilizer has been used mainly to enhance crop yield, whereas lack of access to fertilizer $\mathrm{N}$ in most countries is a major cause of low crop yield and food shortages (Sims et al., 2013). Optimized N fertilizer application rate is one of the predominant aspects achieving food and environment security. Agronomic practices, as well as target yield and soil $\mathrm{N}$ supply need to be considered when determining optimal $\mathrm{N}$ fertilization rate (Ren et al., 2017).

In the present experiments significant $\mathrm{N}$ fertilization, however chosen commercial fertilizers impact on strawberries yield was established (Table 1). Low yield was detected on field without fertilization; it was 2-3 times lower comparing with yield obtained from differently fertilized fields. Higher yield was obtained from fields fertilized with K / N100 and K / Ca / N100 in comparison with control and other analysed samples. What mainly could be explained with used fertilizer composition $\left(\mathrm{N}_{2}, \mathrm{P}_{2} \mathrm{O}_{5}, \mathrm{~K}_{2} \mathrm{O}, \mathrm{MgO}, \mathrm{S}, \mathrm{B}, \mathrm{Cu}, \mathrm{Fe}, \mathrm{Mn}\right.$, Mo and $\mathrm{Zn}$ ) and its positive effect on strawberries yield. Lower yield was obtained using YaraLiva ${ }^{\mathrm{TM}}$ Calcinit fertilizer (Table 1).

Significantly higher nitrates content was obtained in strawberries fertilized with commercial fertilizer Ferticare $^{\mathrm{TM}}$ Kombi 1 and with both commercial fertilizers with extra fertilization with $100 \mathrm{~kg} \mathrm{~N} \mathrm{ha}^{-1}$ (Table 1). Significantly $(\mathrm{p}<0.05)$ lower nitrates content was found in control berries sample and in Ca / N50 and $\mathrm{Ca} / \mathrm{Ca} / \mathrm{N} 50$. Taghavi et al. (2004) revealed the significant effect of different $\mathrm{NO}_{3}{ }^{-}: \mathrm{NH}_{4}{ }^{+}$ratios on 
yield, number of fruits, total nitrogen and nitrate content of different parts of the plants and leaf nitrate reductase activity was determined; also, the strawberry plants showed higher nitrogen content in this ratio compared to the treatment lacking ammonium. Yield and number of fruits are higher in nutrient solutions having both nitrate and ammonium.

Table 1

Assessment of strawberries yield and nitrates content

\begin{tabular}{lccc}
\hline \multicolumn{1}{c}{ Sample } & $\begin{array}{c}\text { Yield, } \\
\text { t ha }\end{array}$ & $\begin{array}{c}\text { Nitrates, } \\
\text { mg kg }^{-1}\end{array}$ & $\begin{array}{c}\text { Amount of Extra, I } \\
\text { and II class berries } \\
\text { \% from yield }\end{array}$ \\
\hline Control & $4.7^{\mathrm{f}}$ & $<36^{\mathrm{d}}$ & $46^{\mathrm{c}}$ \\
$\mathrm{K} / \mathrm{N} 100$ & $15.0^{\mathrm{a}}$ & $76^{\mathrm{b}}$ & $85^{\mathrm{a}}$ \\
$\mathrm{K} / \mathrm{Ca} / \mathrm{N} 100$ & $15.5^{\mathrm{a}}$ & $97^{\mathrm{a}}$ & $86^{\mathrm{a}}$ \\
$\mathrm{K} / \mathrm{N} 50$ & $12.7^{\mathrm{b}}$ & $<36^{\mathrm{d}}$ & $83^{\mathrm{a}}$ \\
$\mathrm{K} / \mathrm{Ca} / \mathrm{N} 50$ & $12.6^{\mathrm{b}}$ & $40^{\mathrm{d}}$ & $80^{\mathrm{a}}$ \\
$\mathrm{Ca} / \mathrm{N} 100$ & $11.3^{\mathrm{c}}$ & $64^{\mathrm{c}}$ & $79^{\mathrm{a}}$ \\
$\mathrm{Ca} / \mathrm{Ca} / \mathrm{N} 100$ & $10.6^{\mathrm{d}}$ & $72^{\mathrm{b}}$ & $81^{\mathrm{a}}$ \\
$\mathrm{Ca} / \mathrm{N} 50$ & $8.4^{\mathrm{e}}$ & $<36^{\mathrm{d}}$ & $82^{\mathrm{a}}$ \\
$\mathrm{Ca} / \mathrm{Ca} / \mathrm{N} 50$ & $8.4^{\mathrm{e}}$ & $<36^{\mathrm{d}}$ & $84^{\mathrm{a}}$ \\
\hline
\end{tabular}

* Results indicated with different letters in the column are significantly $(\mathrm{p} \leq 0.05)$ different.

Significantly $(\mathrm{p}<0.05)$ low amount of Extra, I and II class berries in \% from total yield was obtained for control sample. It was approximately two fold lower in comparison with fertilized berries samples. As a result significant fertilizers impact on berries quality parameters was proved.

Firmness

Pronounced strawberries firmness was obtained for control berries and for berries extra fertilized with $\mathrm{Ca}\left(\mathrm{NO}_{3}\right)_{2}$ during harvesting (Table 2). However, obtained results demonstrate positive $\mathrm{Ca}\left(\mathrm{NO}_{3}\right)_{2}$ influence on the berries quality. However, opposite results were obtained in Lanauskas et al. (2006) research, where calcium nitrate applied to the soil decreased berry firmness. However Conway et al. (2002) in their research concluded that calcium in adequate amounts helps to maintain apple fruit firmness and decreases the incidence of physiological disorders such as water core, bitter pit and internal breakdown.

Soluble solids and $\mathrm{pH}$

Cao et al. (2015) in their experiments asserted that soluble solids content is one of the main parameters for evaluating the nutritive value of strawberry (Fragaria $\times$ ananassa), which is affected by a number of factors including genetics, environmental conditions and cultivation practices. However, Keutgen and Pawelzik (2007) indicated close correlation of strawberries soluble solids, titratable acidity and taste. Non-significant $(p>0.05)$ impact of fertilizer on strawberries soluble solids was detected. In the present research obtained results of fertilized berries was very close to control berry sample. Obtained results are very similar with Cao et al. (2015) research, where content of strawberries soluble solids varies from 7.6 to $11.2^{\circ}$ Brix.
Oliveira et al. (2015) summarized that at the $\mathrm{pH}$ values typically found in fresh and processed fruits and vegetables will most probably be represented by a mixture of equilibrium forms.

Table 2

Assessment of strawberries quality

\begin{tabular}{lccc}
\hline \multicolumn{1}{c}{ Sample } & Firmness, $\mathbf{N}$ & $\mathbf{p H}$ & $\begin{array}{c}\text { Soluble } \\
\text { solids, } \\
{ }^{\circ} \mathbf{B R I X}\end{array}$ \\
\hline Control & $1.22 \pm 0.07^{\mathrm{e}}$ & $3.59 \pm 0.09$ & $10.80 \pm 0.04$ \\
$\mathrm{~K} / \mathrm{N} 100$ & $0.76 \pm 0.02^{\mathrm{c}}$ & $3.47 \pm 0.05$ & $10.30 \pm 0.02$ \\
$\mathrm{~K} / \mathrm{Ca} / \mathrm{N} 100$ & $0.83 \pm 0.02^{\mathrm{b}}$ & $3.57 \pm 0.07$ & $10.50 \pm 0.03$ \\
$\mathrm{~K} / \mathrm{N} 50$ & $0.94 \pm 0.01^{\mathrm{a}}$ & $3.67 \pm 0.09$ & $11.80 \pm 0.03$ \\
$\mathrm{~K} / \mathrm{Ca} / \mathrm{N} 50$ & $0.99 \pm 0.03^{\mathrm{a}}$ & $3.69 \pm 0.08$ & $11.60 \pm 0.01$ \\
$\mathrm{Ca} / \mathrm{N} 100$ & $0.93 \pm 0.02^{\mathrm{a}}$ & $3.61 \pm 0.02$ & $11.00 \pm 0.07$ \\
$\mathrm{Ca} / \mathrm{Ca} / \mathrm{N} 100$ & $0.97 \pm 0.03^{\mathrm{a}}$ & $3.65 \pm 0.03$ & $11.10 \pm 0.02$ \\
$\mathrm{Ca} / \mathrm{N} 50$ & $1.37 \pm 0.04^{\mathrm{e}}$ & $3.61 \pm 0.04$ & $10.90 \pm 0.03$ \\
$\mathrm{Ca} / \mathrm{Ca} / \mathrm{N} 50$ & $1.42 \pm 0.01^{\mathrm{e}}$ & $3.66 \pm 0.07$ & $10.50 \pm 0.07$ \\
\hline * Results indicated with different letters in the column are \\
significantly (p $\leq 0.05)$ different.
\end{tabular}

The $\mathrm{pH}$ modification can influence chemical reactions in phenolic compounds like isomerization or mechanisms of intra- and intermolecular copigmentation as well as self-association between compounds such as anthocyanins and chlorogenic acid, caffeic acid and rutin. Similarly, as soluble solids content, non-significant ( $p>0.05$ ) impact of fertilizer on strawberries $\mathrm{pH}$ was detected too. In the present research obtained results of fertilized berries were very close to control berry sample.

Sensory properties

To have more detailed evaluation of the harvested berries, a sensory evaluation has been done. Following criteria were used - berry external appearance (shape), colour, taste, berry firmness. Strawberries for sensory evaluation were picked at the third harvest in order to avoid first harvest's berry size effect. In the sample without any additional fertilizer berries size did not reach Extra class criteria and were close to $18 \mathrm{~mm}$, so that was the reason for lower external appearance evaluation (Fig. 1). Firmness results show that berries with fertilizer application rate $100 \mathrm{~kg} \mathrm{~N}^{-1}$ are not firm enough. In samples with additional fertilization for cv Polka colour was evaluated better compared to samples of berries with no additional fertilization. Strong flavour was observed in samples with complex fertilization, where strawberries received all necessary nutrients. Also sensory evaluation results show high scores for berries with $50 \mathrm{~kg}$ nitrogen provision with complex fertilizers. Experts could not determine any taste differences in berries that were cultivated with 100 or $50 \mathrm{~kg}$ nitrogen provision with calcium nitrate, therefore, soil provision with nutrients is not sufficient even after the additional fertilization. In order to improve not only harvest mass, but also taste and firmness, it is important to make complex fertilization. Evaluated strawberry size was corresponding to class I and class II berry sizes. Colour of the berries is essential, because that is the first thing that customer 
notices, then follows external appearance, but taste is only rated after purchasing the strawberries. Thereby fertilizers role in harvest formation significantly affects berry sensory attributes.

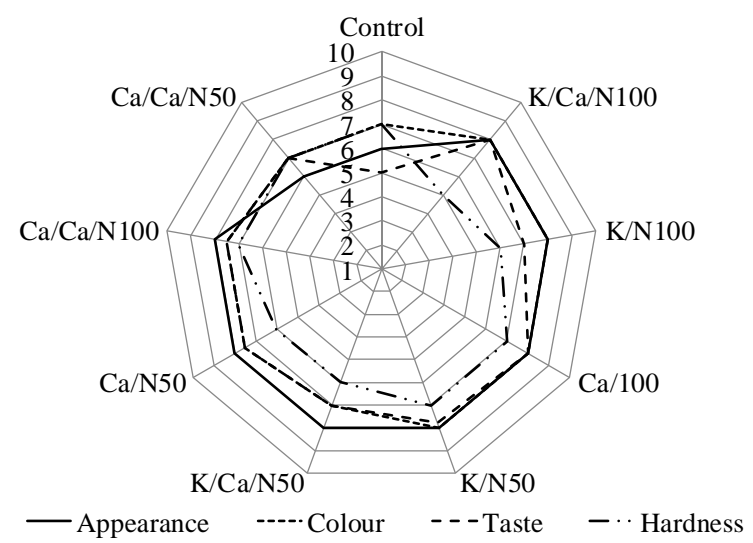

Figure 1. Sensory characteristics of strawberries

The common quality parameters of strawberries for consumer acceptance are appearance, firmness, and flavour. However, the instrumental measures of strawberry quality most reported are colour, firmness, juice, volatile compounds, sugars and organic acids. As well as fruit-to-fruit variation is substantial in fruit firmness and sensory characteristics (Gunness et al., 2009).

\section{Conclusions}

Results of present experiments demonstrate that using complex fertilizers at the rate of $50 \mathrm{~kg}$ nitrogen per hectare, as well as using $100 \mathrm{~kg}$ nitrogen per hectare together with $\mathrm{Ca}\left(\mathrm{NO}_{3}\right)_{2}$, allows producing berries with higher quality parameters.

\section{References}

1. Aguayo E., Jansasithorn R., Kader A.A. (2006) Combined effects of 1-methylcyclopropene, calcium chloride dip, and/or atmospheric modification on quality changes in fresh-cut strawberries. Postharvest Biology and Technology, Vol. 40 (3), p. 269-278.

2. Cao F., Guan C., Dai H., Li X., Zhang Z. (2015) Soluble solids content is positively correlated with phosphorus content in ripening strawberry fruits. Scientia Horticulturae, Vol. 195 (12), p. 183-187.

3. Conway W.S., Sams C.E., Hickey K.D. (2002) Pre- and postharvest calcium treatment of apple fruit and its effect on quality. Acta Horticulturae, Vol. 594, p. 413-419.

4. Filho T.L., Della Lucia S.Ma., Lima R.M., Scolforo C.Z., Carneiro J.C.S., Pinheiro C.J.G., Passamai J.L. Jr. (2014) Irradiation of strawberries: Influence of information regarding preservation technology on consumer sensory acceptance. Innovative Food Science \& Emerging Technologies, Vol. 26, p. 242-247.

5. Hakala M., Lapveteläinen A., Huopalahti R., Kallio H., Tahvonen R. (2003) Effects of varieties and cultivation conditions on the composition of strawberries. Journal of Food Composition and Analysis, Vol. 16 (1), p. 67-80.

6. He-xi Z., Dao-cai C., Qun W., Jun F., Xiao-yu F. (2011) Yield and quality response of cucumber to irrigation and nitrogen fertilization under subsurface drip irrigation in solar greenhouse. Agricultural Sciences in China, Vol. 10 (6), p. 921-930.

7. Jaeger S.R., Axten L.G., Wohlers M.W., Sun-Waterhouse D. (2009) Polyphenol-rich beverages: insights from sensory and consumer science. Journal of the Science of Food and Agriculture, Vol. 89 (14), p. 2356-2363.

8. Keutgen A., Pawelzik E. (2007) Modifications of tasterelevant compounds in strawberry fruit under $\mathrm{NaCl}$ salinity. Food Chemistry, Vol. 105, p. 1487-1494.

9. Laaksonen O., Knaapila A., Niva T., Deegan K.C., Sandell M. (2016) Sensory properties and consumer characteristics contributing to liking of berries. Food Quality and Preference, Vol. 53, p. 117-126.

10. Lanauskas J., Uselis N., Valiuškaitè A., Viškelis P. (2006) Effect of foliar and soil applied fertilizers on strawberry healthiness, yield and berry quality. Agronomy Research, Vol. 4, p. 247-250.

11. Oliveira A., Gomes M.H., Alexandre E.M.C., Poças F., Almeida D.P.F., Pintado M. (2015) Phytochemicals preservation in strawberry as affected by $\mathrm{pH}$ modulation. Food Chemistry, Vol. 170, p. 74-83.

12. Pereira C.C., da Silva E. do N., de Souza A.O., Vieira M.A., Ribeiro A.S., Cadore S. (2016) Evaluation of the bioaccessibility of minerals from blackberries, raspberries, blueberries and strawberries. Journal of Food Composition and Analysis, December, p. 43-49.

13. Pešaković M., Karaklajić-Stajić Ž., Milenković S., Mitrović O. (2013) Biofertilizer affecting yield related characteristics of strawberry (Fragaria $\times$ ananassa Duch.) and soil micro-organisms. Scientia Horticulturae, Vol. 150, p. 238-243.

14. Pritts M. (2002) Growing strawberries, healthy communities, strong economies and clean environments: what is the role of the researcher? Acta Horticulturae, Vol. 567, p. 411-417.

15. Ren T., Liu B., Lu J., Deng Z., Li X., Cong R. (2017) Optimal plant density and $\mathrm{N}$ fertilization to achieve higher seed yeld and lower $\mathrm{N}$ surplus for winter oilseed rape (Brassica napus L.). Field Crops Research, Vol. 204 (15), p. 199-207.

16. Sharma R.R., Krishna H., Patel V.B., Dahuja A., Singh R. (2006) Fruit calcium content and lipoxygenase activity in relation to albinism disorder in strawberry. Scientia Horticulturae, Vol. 107 (2), p. 150-154.

17. Sims J.T., Ma L., Oenema O., Dou Z., Zhang F.S. (2013) Advances and challenges for nutrient management in China in the 21st century. Journal of Environmental Quality, Vol. 42, p. 947-950.

18. Taghavi T.S., Babalar M., Ebadi A., Ebrahimzadeh H., Asgari M.A. (2004) Effects of nitrate to ammonium ratio on yield and nitrogen metabolism of strawberry (Fragaria x Ananassa cv. Selva). International Journal of Agriculture \& Biology, Vol. 4 (6), p. 1-4.

19. Wang B., Lai T., Huang Q., Yang X.-M., Shen Q.-R. (2009) Effect of $\mathrm{N}$ fertilizers on root growth and endogenous hormones in strawberry. Pedosphere, Vol. 19, p. 86-95.

20. Gunness P., Kravchuk O., Nottingham S.M., D'Arcy B.R., Gidley M.J. (2009) Sensory analysis of individual strawberry fruit and comparison with instrumental analysis. Postharvest Biology and Technology, Vol. 52 (2), p. 164-172. 